
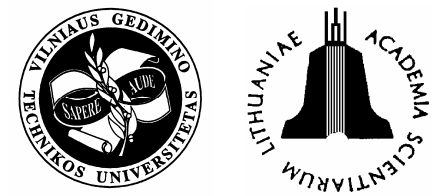

\title{
INFLUENCE OF CONCRETE AND FIBRE CONCRETE ON THE LOAD-CARRYING CAPACITY AND DEFORMABILITY OF COMPOSITE STEEL-CONCRETE COLUMNS
}

\author{
Elżbieta Szmigiera \\ Faculty of Civil Engineering, Warsaw University of Technology, Armii Ludowej Street 16, \\ 00-637 Warsaw.E-mail: E.Szmigiera@il.pw.edu.pl \\ Received 05 Dec 2005; accepted 26 March 2006
}

\begin{abstract}
The report presents the results of laboratories' tests on steel columns strengthened by concrete casing. During testing of steel I-shape column the strength of concrete casing and the way of the column loading were parameters subjected to changes. The possibility of increasing load capacity of columns by strengthening the supporting zones was checked, too. On the basis of tests performed, it has been stated that there is a considerable effect of concrete casing on the performance and capacity of steel columns. Possibility of increasing the load capacity of columns by making heads of fibre concrete has been shown.
\end{abstract}

Keywords: composite columns, steel, concrete, fibre concrete, load-carrying capacity, strains, strengthening.

\section{Introduction}

Composite steel-concrete construction has been widely used in many structures such as buildings and bridges. The concrete-encased composite column is one of the common composite structural elements. At the same time, due to the traditional separation of structural steel and reinforced concrete design and construction, this type of columns has not received the same level of attention as steel or reinforced concrete columns.

Composite structures from concreted steel sections show considerably larger stiffness, stability and load capacity in comparison with steel constructions. An increase of corrosion and fire resistance is an additional advantage of concreting steel elements $[1,2]$.

Recently, many studies have examined the behaviour and strength of composite structures, as well concrete encased composite columns. In the world's references there are some handbooks and papers, in which authors try to systematise types of composite structures and methods of their calculation [3-5]. It is partially connected with, including codes and standards, information given to the procedure pertaining to be the so-called general method. One can find information [6] about the following: taking into account geometrical and structural imperfections, yield point dispersion, modelling concrete, reinforcing steel and structural steel behaviour, modelling time dependent concrete behaviour and the inclusion of the tension stiffening effect. The background information and modification of simplified design method for composite columns to a method with initial imperfections are given in [3].

In the Pacific regions of Taiwan and Japan, the composite frame system, beam-columns is commonly adopted as the seismic-force-resisting system in building construction. The behaviour of this system by analytical models is presented in [7].

In the author's opinion, recent investigations proceed in the direction of checking and testing the behaviour of typical types of composite columns with applied new solutions, eg partially encased composite columns with batten plates [8-9], or new materials, eg highstrength concrete [10].

Design for axial compression requires a consideration of cross-section capacity as well as slenderness effects. Slenderness has an impact on buckling of the column under concentric axial force. Buckling of very slender columns is a phenomenon based on the elastic flexural stiffness. Buckling of less slender columns involves a combined elastic and post-elastic flexural deformation [5]. In the author's opinion, there are more important parameters, significantly influencing the capacity of composite columns, among others: method of the column attachement to the base and the way of applying load to the cross-section. Not all of them are considered in recommendations of valid standards.

The paper presents results of testing steel-concrete composite columns, composed of I-shape steel covered entirely by concrete casing. Columns of such section are widely applied in general building, particularly in highrise buildings. Determination of an effect of concrete strength and the way of applying load to the capacity of composite columns were the main objectives of performed tests. The paper presents also proposals for increasing the load capacity of studied elements by strengthening zones, which underwent failure as a result of an applied load. 


\section{Description of experimental tests}

Tests were performed on columns composed of rolled steel I-shape HEA 160 entirely covered by casing of concrete of various classes. In composite section of column four longitudinal ribbed bars of diameter $\varnothing 12 \mathrm{~mm}$ were placed as well as stirrups from plain steel of $\varnothing 6 \mathrm{~mm}$. The tests were performed on elements in technical scale. Length of elements was $2500 \mathrm{~mm}$, while dimensions of cross-section: $260 \times 260 \mathrm{~mm}$. Yield point of I-shape steel was $282 \mathrm{MPa}$ and yield point of longitudinal bar steel $317 \mathrm{MPa}$. The columns were produced and tested in the Laboratory of Buildings' Construction Institute of Warsaw University of Technology (Fig 1).

Sections of columns taken for testing fulfilled the requirements in [11].

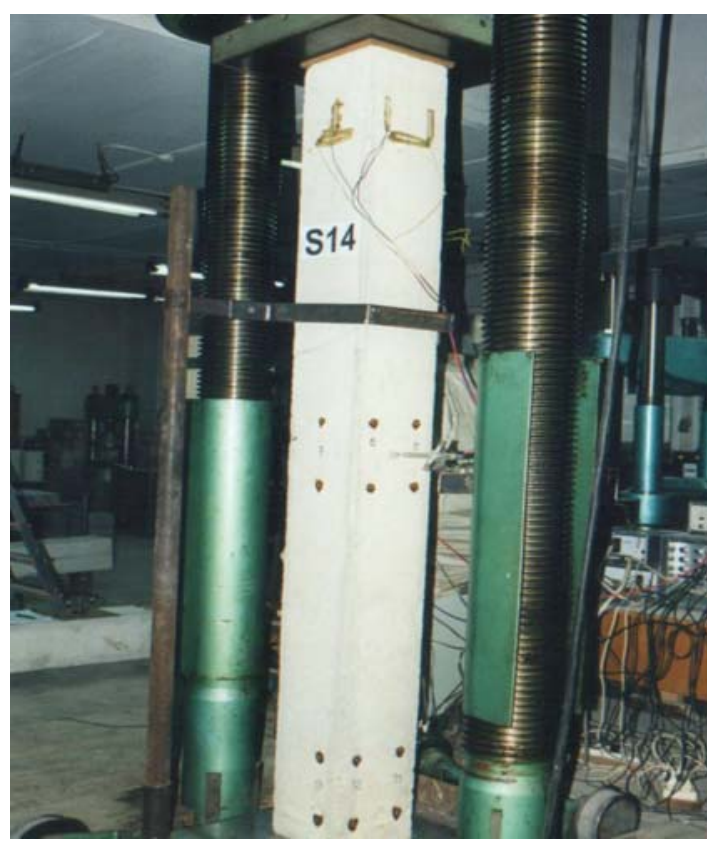

Fig 1. Testing stand of the columns

Altogether 16 composite columns and one steel column made of the same steel I-shape were tested [12, 13].

Elements were loaded in hydraulic press by axial compressive force down to failure. During testing of columns the initial changing parameters were: strength of concrete surrounding the steel section and the way of application of axial compressive force. Two schemes of loading were applied. In the first case loading was applied to the whole composite section. In the second one the composite column was loaded by steel I-shape protruded from column section (Fig 2).

At every increase of the applied loading measurements of deformations of steel section as well as of concrete were made.

Measurements were made in 3 sections: at the upper edge, in the middle of span and at the bottom basis. Electric resistance wire strain gauges and dial extensometers were applied. Horizontal displacements of columns were measured by inductive gauges (Fig 3).

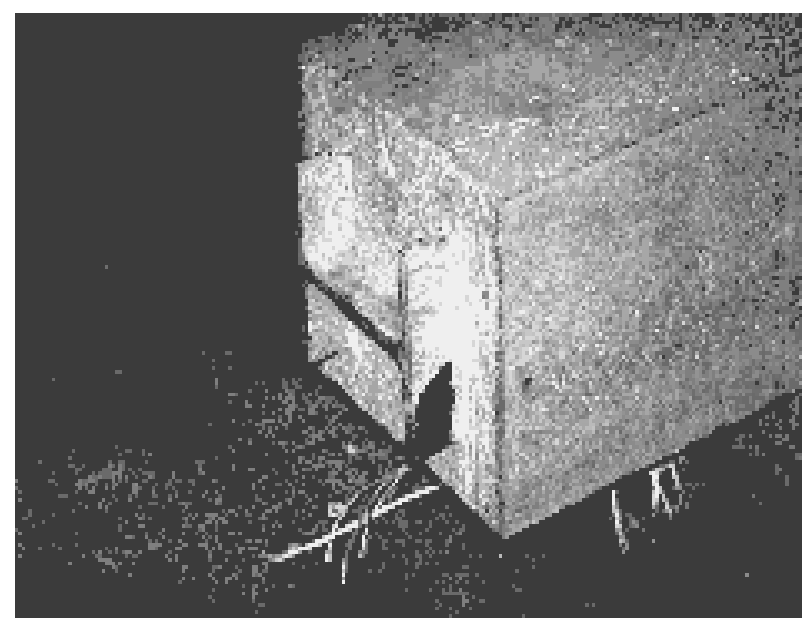

Fig 2. The column head with a shape protruded from a column section

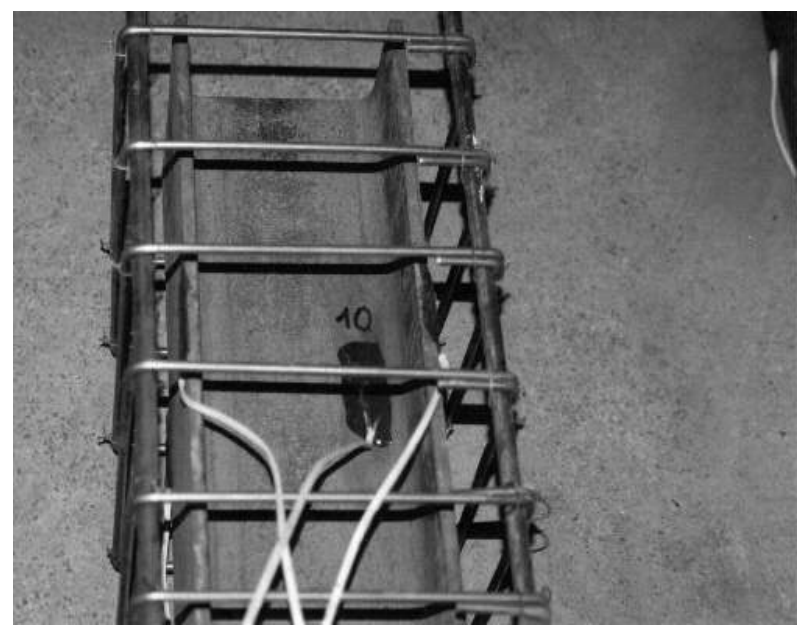

Fig 3. The construction steel and bars prepared to encased concrete

The steel column was tested as the first element failed under the axial force of $990 \mathrm{kN}$. The failure resulted from the loss of general stability. The displacement of the column in the middle of height was equal to $2,5 \mathrm{~cm}$ and $1,5 \mathrm{~cm}$ respectively to principal axes of inertia of I-shape.

It can be stated from the observations during the tests that concreting the steel column of I-shape section results in a considerable increase of load capacity as well as changes the character of failure of composite columns. The results of tests on steel column S0 and chosen composite columns are shown in Table 1.

For composite elements the capacity increases with a growth of concrete strength, but the character of failure is independent of the concrete class.

The cause of failure of the composite column, in which axial force was applied to the whole surface of section, was due to concrete crushing in the upper supporting zone (Fig 4).

The range of destruction zone depended on strength of concrete casing and was equal to $40-60 \mathrm{~cm}$. On the rest part of columns no cracks were observed during testing. This results from the fact that during testing columns 
were fixed to supports asymmetrically. At the upper support the columns were fixed to bearings, while at the bottom part the fixing scheme was near the free support.

Table 1. Summary of test results for steel column SO and for selected composite columns

\begin{tabular}{c|c|c|c|c|c}
\hline $\begin{array}{c}\text { Column } \\
\text { denotation }\end{array}$ & $\begin{array}{c}\text { Concrete } \\
\text { class }\end{array}$ & $\begin{array}{c}\text { Com- } \\
\text { pressive } \\
\text { strength } \\
{[\mathrm{MPa}]}\end{array}$ & $\delta$ & $\begin{array}{c}\text { Failure } \\
\text { load } \\
{[\mathrm{KN}]}\end{array}$ & $\begin{array}{c}\text { Load } \\
\text { capacity } \\
\text { by EC 4 } \\
{[\mathrm{kN}]}\end{array}$ \\
\hline $\mathrm{S} 0$ & - & - & - & 990 & 670 \\
\hline $\mathrm{S} 1$ & $\mathrm{C} \mathrm{30/37}$ & 41,9 & 0,32 & 2300 & 2010 \\
\hline $\mathrm{S} 2$ & $\mathrm{C} 25 / 30$ & 40,6 & 0,32 & 2190 & 2003 \\
\hline $\mathrm{S} 4^{*}$ & $\mathrm{C} \mathrm{25/30}$ & 38,7 & - & 2290 & - \\
\hline $\mathrm{S} 6$ & $\mathrm{C} 45 / 55$ & 59,9 & 0,25 & 3100 & 2454 \\
\hline $\mathrm{S} 10-\mathrm{F}^{* *}$ & $\mathrm{C} \mathrm{30/37}$ & 41,7 & - & 2900 & 2005 \\
\hline $\mathrm{S} 13$ & $\mathrm{C} 16 / 20$ & 28,9 & 0,39 & 2000 & 1730 \\
\hline $\mathrm{S} 15$ & $\mathrm{C} 12 / 15$ & 22,9 & 0,44 & 1500 & 1497 \\
\hline
\end{tabular}

where:

$\delta$ - the steel contribution ratio - the proportion of the squash load of the section that is provided by the structural steel member (without unit),

* - column loaded through steel core,

** - column with fibre concrete head (see item 3 ).

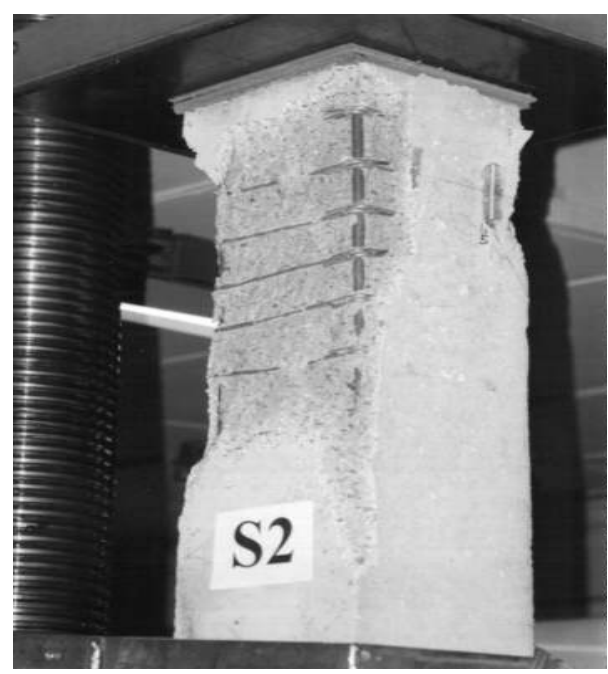

Fig 4. Character of destruction of composite columns loaded over the composite cross-section

Testing columns, in which load was applied by steel core, protruded from column section (Fig 5) confirmed the author's supposition that the way of loading had a considerable effect on the character of work and failure of element. The failure force for this type of column had a comparable value to force got during testing column made of the concrete of the same class, in which load was applied to the whole composite cross-section. However, the limit state of cracking was decisive for failure of the column with protruded steel core. During loading, the applied force through steel core caused a gradual dipping of the core into concrete casing. Due to this, on the surface of concrete long, deep cracks developed. The cracks ran along the column and they reached about $30 \mathrm{~cm}$ below half of its length.

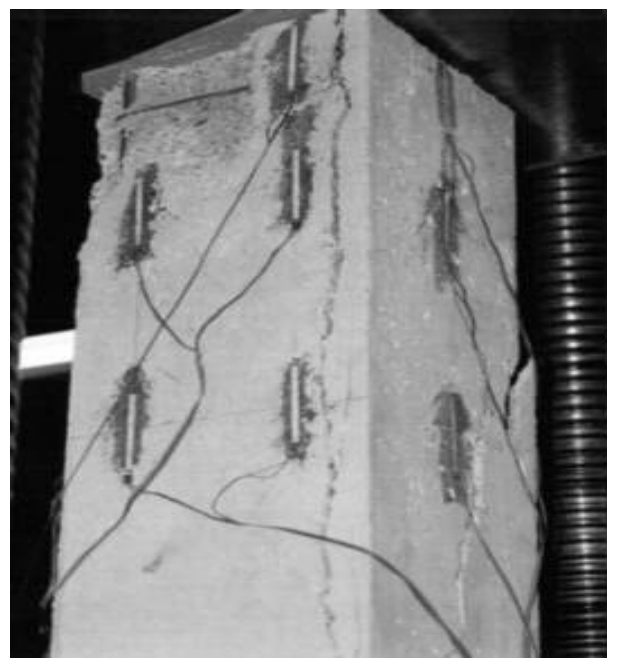

Fig 5. Character of destruction of composite columns loaded through the steel core

At some value of load steel core hid entirely in concrete casing. At further increase of the load the tested element behaved so as column, in which load was applied to whole composite section. However, cracks formed earlier exhausted the limit state of cracking; thus, further use of element was impossible.

The strains of steel and concrete in two crosssections at the upper part of column loaded by steel core are shown in Figs 6, 7. Those figures show that values of strains for steel and concrete are completely different. Dependence force - strains in Fig 6 shows that during loading near the upper edge strains of steel increased very quickly, while values of strains of concrete were near zero. Farther from the upper edge, concrete started to participate in bearing load (Fig 7); consequently, values of strains in steel were smaller than in the first crosssection (Fig 6).

On the basis of the reading gauges (and the observations of behaviour of the column during testing too), it has been concludedt hat the way of loading column through steel core protruded from the column causes a loss of bond between steel and concrete.

The differences in behaviour between columns loaded on the whole section and through steel section were observed by the gauges. These differences are shown in Figs 8, 9.

It can be seen clearly on the basis of this drawing that loading the column through protruded steel core causes break of bond between I-shape steel and surrounding concrete. And it has an essential effect on the work of element.

\section{Testing columns with head of fibre concrete}

The character of destruction, observed during testing, of steel columns with concrete casing, has induced the author to examine the work of the composite column 


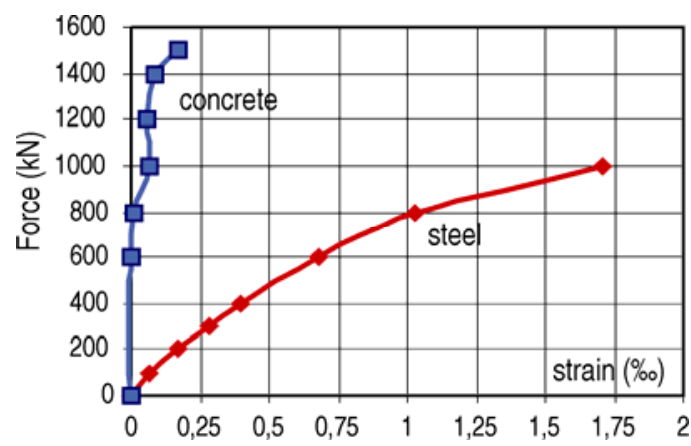

Fig 6. Strains of steel and concrete in cross-section situated $5 \mathrm{~cm}$ from the upper edge



Fig 7. Strains of steel and concrete in cross-section situated $25 \mathrm{~cm}$ from the upper edge

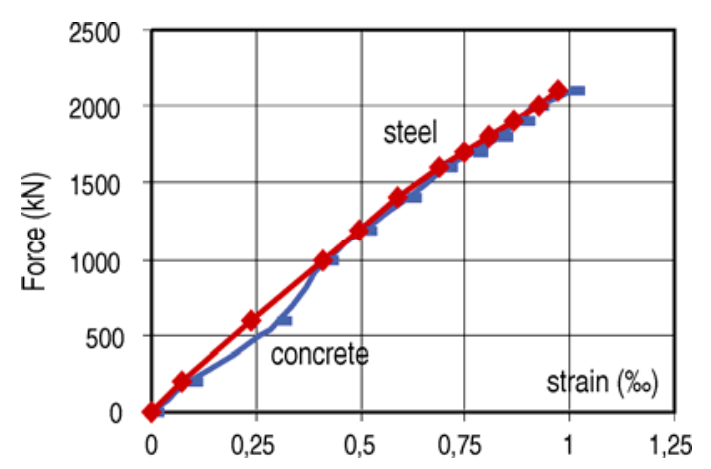

Fig 8. Strains of steel and concrete in the middle height of composite column loaded over the whole composite cross-section

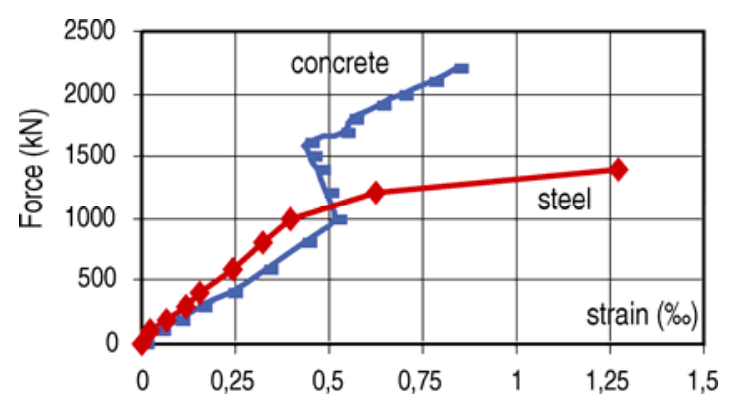

Fig 9. Strains of steel and concrete in the middle height of composite column loaded through steel core cross-section with a strengthened head. The column was produced similarly to previous studied elements, ie from entirely encased I-shape HEA 160. To manufacture the column concrete of class C 25/30 was decided and to concrete the upper part of the column on height of $60 \mathrm{~cm}$ of the same concrete but with an addition of 1,5\% steel fibres. This value is not economic, but it was much smaller than the critical one. It was used to reach a plain effect. The compressive strength of concrete of the column was related to concrete class C 25/30, while the tensile strength of concrete head was almost twice higher than the corresponding one for this class. The composite column with fibre concrete head was subjected to load acting onto the whole composite section.

During testing of this column, at the moment of loading element by the force equal to $2190 \mathrm{kN}$, no cracks were found on its surface. At this force the first crack of $4 \mathrm{~cm}$ length was noticed, running this time at the bottom edge of the column.

The composite column with a head from fibre concrete failed at the load of $2900 \mathrm{kN}$ (Table 1). At this load the upper part of the column has been crushed on the length about $40 \mathrm{~cm}$. It was not observed, however, falling away of concrete casing held by micro-reinforcement.

Testing the column with a head of fibre concrete showed that strengthening the supporting zone would influence the increase of its load capacity. In this case strengthening resulted from an addition of steel fibres and restraint lateral strains of concrete casing in the supporting zone. This increase of load capacity of studied column was about $30 \%$. The value of destructive force was comparable with that force developed during testing of column from the concrete class C 45/55 (Table 1). The results of testing columns with heads were so much encouraging, that it was decided to continue further the investigations. After loading the last three composite columns, which also were destroyed by concrete crushing at the upper edge, it was decided to use them again for a renewed testing. Concrete was removed away from the damaged part of the column and this part of section was concreted again by concrete with steel fibres. The performed tests results are in Table 2.

On the basis of data in Table 2, it can be seen that making heads in earlier failed columns caused an increase of load capacity of these columns at the second loading,

Table 2. Comparison of test results for columns loaded twice

\begin{tabular}{l|c|c|c}
\hline Column denotation & $\mathrm{S} 14$ & $\mathrm{~S} 15$ & $\mathrm{~S} 16$ \\
\hline $\begin{array}{l}\text { Average concrete compressive } \\
\text { strength in columns [MPa] }\end{array}$ & 25 & 22,9 & 20,2 \\
\hline $\begin{array}{l}\text { Average concrete tensile strength } \\
\text { in columns [MPa] }\end{array}$ & 2,63 & 2,09 & 1,97 \\
\hline $\begin{array}{l}\text { Failure load - columns without } \\
\text { heads [kN] }\end{array}$ & 1800 & 1500 & 1500 \\
\hline $\begin{array}{l}\text { Average concrete compressive } \\
\text { strength in heads [MPa] }\end{array}$ & 28,7 & 28,7 & 28,7 \\
\hline $\begin{array}{l}\text { Average concrete tensile strength } \\
\text { in heads [MPa] }\end{array}$ & 3,73 & 3,73 & 3,73 \\
\hline $\begin{array}{l}\text { Failure load - columns with heads } \\
{[\mathrm{kN}]}\end{array}$ & 2490 & 2320 & 2300 \\
\hline
\end{tabular}


on average $48 \%$. The tests confirmed the earlier results. One should remember that such an increase of load capacity got columns already earlier loaded to the value of failure load.

It was observed during testing that the behaviour and character of destruction of these columns were different than those described earlier for columns with a fibre concrete head S10-F.

The differences in character of visible destruction are shown in Figs 10 and 11.

Fig 10 shows that the column S10-F failed due to concrete crushing in a small part across fibre concrete head. It can also be stated that there was no falling away fragments of concrete, as it took place in the columns without heads.



Fig 10. Character of destruction of column with fibre concrete head, made of the same concrete mix as the whole column (S10-F)

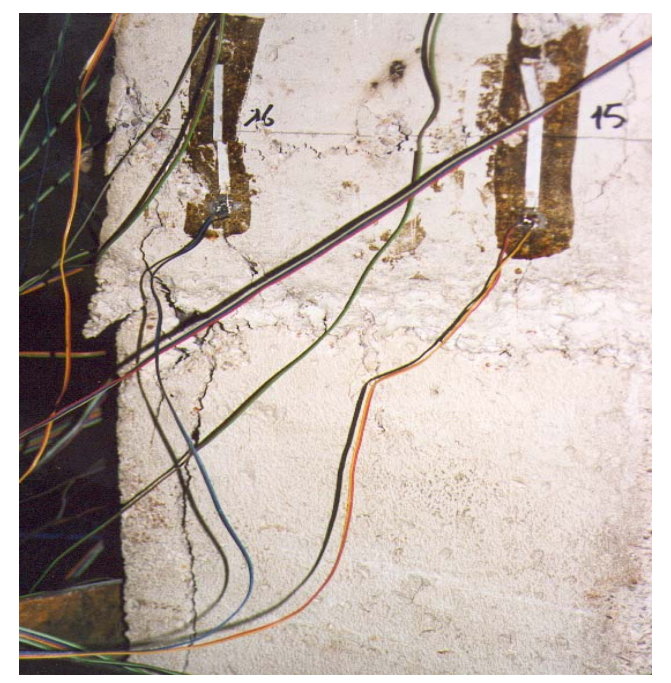

Fig 11. Reloaded column at the moment of failure. In the picture a visible fragment of column under head from fibre concrete is seen
During the increase of loading, the columns in which after earlier failure fibre concrete heads were made, they underwent a gradual cracking. However, at the force causing the second failure, there occurred a violent crack at the point of contact of the head with the rest of column. The head "sat down" on the remaining part of element, separating itself clearly (Fig 11).

It can be seen in Fig 11 that under the head, in the casing from plain concrete, there appeared long, wide cracks. Similarly as in a previous case, there was no falling away of concrete from the head because it was kept by micro-reinforcement.

The reason of such behaviour of the columns was the difference between compressive strength in the concrete head and in the concrete casing of the remaining part of the column. Another essential reason was that the heads of these columns were made much later than the columns themselves.

\section{Analysis of the behaviour of steel-concrete composite columns}

\section{1. Analysis of the laboratory tests}

On the basis of the obtained results, it has been possible to formulate the following conclusions:

- failure of concreted composite column depends on the state of stresses in concrete casing;

- use of concrete of a higher class causes an increase of load capacity of composite column, but it has no influence on the change of character of its failure (see also Figs 12, 13);

- at a constant section of concreted column, an increase of concrete strength is not the only effective way for increasing load capacity of the column; strengthening these zones of the composite columns in which concentration of stresses resulted from an applied load is an another method;

- one of the effective methods of strengthening supporting zones is making heads from fibre concrete;

- the best effects of strengthening are achieved, if head is made of concrete of similar mechanical properties as concrete of casing in the remaining part of the column; one should remember about executing a correct connection of head concrete with an earlier concreted fragment of the column;

- during designing the strengthening of steel columns by concrete casing one should pay attention to the way of introduction of load to element: loading a concreted column over the whole composite section is the most profitable scheme; if a realisation of such a way of loading is impossible, improvement of conditions of work of concreted steel column can be possibly reached by:

- additional connectors, assuring better cooperation of steel and concrete,

- making a washer (for example, from steel plate) for the place, where a load is applied; such a washer changes a scheme of applied compressive force, aiming at distribution of load in the whole composite section; 
- results of tests on concreted columns (re-loaded again after making heads from fibre concrete), indicate the possibility to obtain essential effects by strengthening by this method the columns in existing constructions.

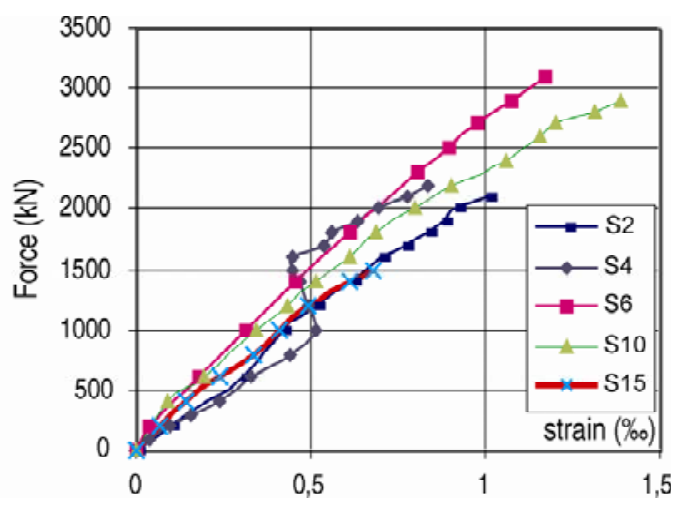

Fig 12. Strains of concrete core in different testing types of composite columns



Fig 13. Strains of construction steel in different testing types of columns (blue line for steel column S0)

\subsection{Numerical analysis of composite columns}

Results of laboratory testing were used for verifying the non-linear FE models developed for studying the response of composite columns in axial compression (for data of columns S2 and S4). The computer code ABAQUS was used [14-16]. The finite element (FE) models developed use 3 D solid elements with REBAR option standing for the reinforced concrete structure and 2D shell elements to represent the I-section steel column.

The primary objective is to develop the FE models that could represent the behaviour of columns tested in axial compression in the laboratory. A parametric study was conducted with respect to the concrete-steel interaction and the boundary conditions. These factors play the most critical role on the onset of the local failure mechanism and on reaching the ultimate load corresponding to the development of the global failure mechanism.

Three different cases of modelling the boundary conditions are considered. In the first case both ends of column were fully restrained, in the second one the ends were simply supported and in the third one - simply supported with an asymmetrical attachment. In each case two possibilities of concrete-steel interaction were taken into account: the full composite action between the inner steel I-section and the outer concrete and no composite action (the concrete is treated only as an encasing).

It appears that the model of column with an asymmetrical attachment enables the closest modelling of the effect of boundary conditions on the behaviour observed during laboratory investigations. It can be concluded by Fig 14 where the diagrams of the maximum strain obtained from laboratory results and numerical analysis are drawn.

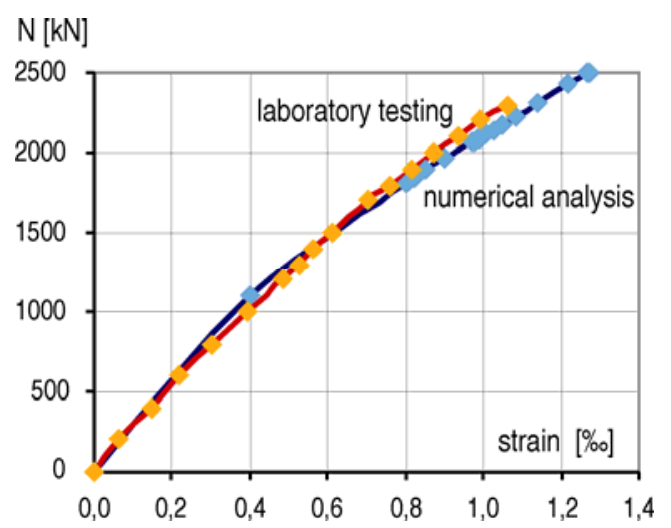

Fig 14. Load-strain characteristic for the section in middle of the length of a composite column

The development of the idealised model of steelconcrete composite columns opened up possibilities for conducting further research on the behaviour of composite columns with a use of ABAQUS programme. When the estimation of values of strain and stress in steel and concrete was made available, then the distribution of stresses and strains along the whole length of the column was established. On the basis of this analysis, one can note that there is a $3 \mathrm{D}$ stress state existing in the concrete core that has a significant influence on the load bearing capacity of encased composite columns.

In Fig 15 the load displacement (axial shortening) characteristic of the composite column behaviour is shown.

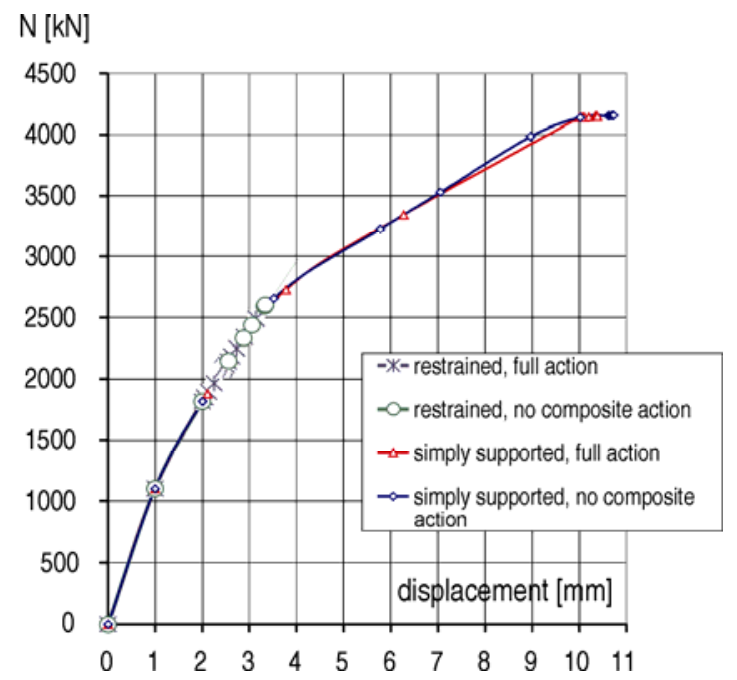

Fig 15. Load displacement characteristic of the composite column for the different conditions of boundary and interaction between steel and concrete 
Different boundary conditions were included and two cases of full composite action between steel and concrete and no composite action considered. From Fig 15 it appears that the boundary conditions in the composite column base have a great influence on their load bearing capacity. The highest value of the column ultimate load is reached in case of the column simply supported at both ends.

The load displacement characteristic shows also that the interaction between steel and concrete does not produce any influence on the capacity of composite columns.

\section{Conclusions}

The performed tests indicated the effectiveness of strengthening steel columns by concrete casing. Analysis of tests showed also that the behaviour and character of failure of such columns are of a very complex kind and they depend on many factors. No all of them are considered in recommendations of actually valid standards.

\section{References}

1. HAß, R.; MEYER-OTTENS, C. and QUAST, U. Verdbundbau Brandschutz Handbuch. Ernst \& Sohn, Berlin, 1989. $287 \mathrm{p}$.

2. WANG, Y. C. Steel and composite structures: behaviour and design for fire safety. Spon Press, Tylor \& Francis Group, London and New York, 2002. 352 p.

3. LINDNER, J. and BERGMANN, R. Zur Bemessung von Verbundstützen nach DIN 18800 Teil 5. Stahlbau, 67 (7), 1998, p. 536-546.

4. VAYAS, I. Verbundkonstruktionen auf der Grundlage des Eurocode 4. Ernst \& Sohn, A Wiley Co, 1998. 347 p.

5. VIEST, I. M.; COLACO, J. P. and FURLONG, R. W. Composite construction design for buildings. McGrawHill Co, 1997. 496 p.

6. KLEINSCHMITT, J. Erläuterungen und kritische Anmerkungen zur nichtlinearen Berechnung von Verbund- stützen nach Din V 18800-5. Bauingenieur, Band 80, May 2005. 9 p.

7. LEE, T.-K. and PAN, A. D. E. Analysis of composite beam-columns under lateral cyclic loading. Journal of Structural Engineering, 127 (2), Feb 2001, p. 186-193.

8. CHICOINE, T.; TREMBLAY, R.; MASSICOTTE, B.; RICLES, J. M. and LU, Le-Wu. Behaviour and strength of partially encased composite columns with built-up shapes. Journal of Structural Engineering, 128 (3), Mar 2002, p. 279-288.

9. HUNAITI, Y. M. and FATTAH, B. A. Design considerations of partially encased composite columns. In Proceedings of Institution of Civil Engineers, 106, Feb 1994, p. $75-82$.

10. EL-TAWIL, S. and DEIERLEIN, G. G. Strength and ductility of concrete encased composite columns. Journal of Structural Engineering, 125(9), Sept 1999, p. 10091019.

11. Eurocode 4: Design of composite steel-concrete structures - Part 1-1: General rules and rules for buildings. European Committee for Standardisation, Brussels, Belgium, Dec 2004. 118 p.

12. ŻÓŁTOWSKI, W.; SZMIGIERA, E. Effect of concrete on load capacity and way of failure of composite steelconcrete columns. In Proc of XVII Scientific-Technical Conference. Jadwisin, 2000, p. 91-120.

13. ŻÓŁTOWSKI, W.; SZMIGIERA, E. Load capacity and deformability of axially compressed steel elements strengthened by concrete casing. In Proc of X International Scientific-Technical Conference Metal Structures. Gdańsk, June 5-8 2001, p. 215-222.

14. ABAQUS Theory manual. Version 5.8. Hibbitt, Karlsson and Sorensen, Inc., Pawtucket, 1998. 727 p.

15. ABAQUS/Standard user's manual. Version 5.8. Hibbitt, Karlsson and Sorensen, Inc., Pawtucket, 1998. 1634 p.

16. ABAQUS/Standard verification manual. Version 5.8. Hibbitt, Karlsson and Sorensen, Inc., Pawtucket, 1998. 1827 p.

\section{BETONO IR DISPERSIŠKAI ARMUOTOJO BETONO ITAKA KOMPOZITINIŲ PLIENO IR BETONO KOLONŲ LAIKOMAJAI GALIAI IR DEFORMAVIMUISI}

\section{E. Szmigiera}

\section{Santrauka}

Pateikiami betono apvalkalu stiprintų plieninių kolonų eksperimentinių tyrimų rezultatai. Bandytos I formos plieninės kolonos, esant skirtingam betoninio apvalkalo stipriui bei apkrovos tipui. Taip pat nagrinèta kolonu laikomosios galios didinimo galimybė stiprinant atrėmimo zonas. Remiantis atliktų tyrimų rezultatais, nustatyta, kad betono apvalkas turi didelę įtaką plieninių kolonų elgsenai ir laikomajai galiai. Parodyta, kad kolonų laikomoji galia padidèja ịrengus dispersiškai armuotojo betono galvenas.

Reikšminiai žodžiai: kompozitinès kolonos, plienas, betonas, dispersiškai armuotasis betonas, laikomoji galia, deformacijos, stiprinimas.

Elżbieta Danuta SZMIGIERA. PhD, Eng. Seventeen years of teaching and research experience at Faculty of Civil Engineering of the Warsaw University of Technology, Poland, Dept of Concrete Structures. Mainly she is researching different aspect of behaviour and design theory of composite steel-concrete structures. She has been also invited to deliver the postgraduate course on the behaviour and design for fire safety of steel and composite steel-concrete structures in the Main School of Fire Service in Warsaw. She has been involved in standardisation exercise in Poland. The member of the Technical Committee 195 on Concrete Prefabrication, Poland. She is also a member of Committee of Science of Polish Union of Civil Engineers and Technicians. Nowadays she performs the functions of Vice Dean for students affairs at Faculty of Civil Engineering of the Warsaw University of Technology. 